УДК 595.763.2/.3:591.522 (571.66)

\title{
МАТЕРИАЛЫ К ФАУНЕ СТАФИЛИНИД (СОLЕОРТЕRА: STAPHYLINIDAЕ) ТУНДР КАМЧАТКИ (подсемейства STENINAE, EUAESTHETINAE, PAEDERINAE и STAPHYLININAE)
}

\author{
Рябухин А. С. \\ ФГБУН Институт биологических проблем Севера ДВО РАН, г. Магадан \\ E-mail: asr@ibpn.ru
}

\begin{abstract}
Представлены результаты обобщения литературных данных и обработки материала, собранного в различных районах Камчатки. Для фауны тундр выявлены 22 вида стафилинид из 7 родов, относящихся к подсемействам Steninae, Euaesthetinae, Paederinae и Staphylininae. Видовая принадлежность Quedius (Raphirus) cf. fellmani (Zetterstedt, 1838), Q. (R.) cf. fulvicollis (Stephens, 1833) и Q. (R.) cf. sublimbatus Mäklin, 1853 из подсемейства Staphylininae нуждается в уточнении. Составлен аннотированный список видов. Закартированы пункты сборов.
\end{abstract}

Ключевые слова: стафилиниды, Staphylinidae, фауна, тундры, Камчатка.

DOI: $10.34078 / 1814-0998-2021-1-81-88$

Эта работа является заключительной частью обзора фауны стафилинид тундр Камчатки. Сведения о подсемействах Omaliinae, Proteininae, Pselaphinae, Tachyporinae и Oxytelinae были опубликованы ранее (Рябухин, 2020). В данном сообщении приводятся результаты обработки материалов, собранных в 1989 и 2004-2013 гг., по четырем подсемействам: Steninae, Euaesthetinae, Paederinaе и Staphylininae.

Для горных тундр характерно почти полное отсутствиестафилинид. В окрестностяхпос.Эссо, в гольцовом поясе, в травяно-кустарничковых тундрах обнаружены лишь 4 вида из 3 подсемейств: Omaliinae - Acidota quadrata (Zetterstedt, 1838) и Arpedium brachypterum (Gravenhorst, 1802), Staphylininae - Quedius mesomelinus (Marsham, 1802) и Tachyporinae - Tachyporus sp. Лобкова, Семенов (2012: 100). Отмечают в горных кустарничковых тундрах Кроноцкого заповедника также 4 вида: Acidota crenata (Fabricius, 1793) (подсемейство Omaliinae), Tachinus elongatus Gyllenhal, 1810 (Tachyporinae), Philonthus ebeninus (Gravenhorst, 1802) и Quedius kamchaticus Smetana, 1976 (Staphylininae).

Подавляющее большинство материала собрано в низинных тундрах, которые, как правило, в разной степени и сочетаниях закустарены ивами, ольхой, березой Миддендорфа, изредка - кедровым стлаником. Кустарнички представлены ивами, карликовой березкой, багульником, шикшей, голубикой, брусникой, реже - морошкой, часто в

(C) Рябухин А. С., 2021 различных комбинациях. Травянистая растительность выражена весьма неравномерно - от крайне разреженного разнотравья до сплошных, часто закочкаренных, злаковых, осоковых или осоковопушицевых формаций. Напочвенный покров составляют различные виды мхов и лишайников.

\section{МАТЕРИАЛ И МЕТОДЫ}

При сборе материала применялись следующие методы: ручная разборка или просеивание на сифтере почвенной подстилки и других субстратов, сбор эксгаустером с открытых поверхностей и в различных укрытиях. Также устанавливались почвенные ловушки (пластиковые стаканы объемом 0.25 л, без фиксатора), выемку пойманного материала из которых выполняли ежедневно. В стационарных условиях применяли фото- и термоэклекторы и светоловушки. При благоприятных погодных условиях проводили лов сачком при вечернем лёте на фоне неба. Также производилось обкашивание сачком кустарниковой и травянистой растительности. Собранный материал замаривали хлороформом, сортировали по таксономическим группам и помещали на ватные матрасики или в пробирки с 70\%-ным этиловым спиртом. Дальнейшая его обработка проводилась в лаборатории. Все пункты сборов отмечены на рисунке.

Места хранения материала: Зоологический институт РАН (Санкт-Петербург), Институт биологических проблем Севера ДВО РАН (Магадан), Датский музей Естествознания Natural History Museum of Denmark (Копенгаген, Дания). 


\section{РЕЗУЛЬТАТЫ И ОБСУЖДЕНИЕ}

Всего были выявлены и идентифицированы 22 вида стафилинид из 7 родов, относящихся к подсемействам Steninae, Euaesthetinae, Paederinae и Staphylininae. Объем собранного материала в количественном выражении составляет около 500 экз. Видовая принадлежность Quedius (Raphirus) cf. fellmani (Zetterstedt, 1838), Q. (R.) cf. fulvicollis (Stephens, 1833) и $Q$. (R.) cf. sublimbatus Mäklin, 1853 из подсемейства Staphylininae нуждается в уточнении, все материалы по роду Quedius Stephens, 1829, собранные на Камчатке в 20042013 гг., в настоящее время переданы для идентификации в Датский музей Естествознания.

В аннотированном списке видов учтены последние номенклатурные изменения и данные

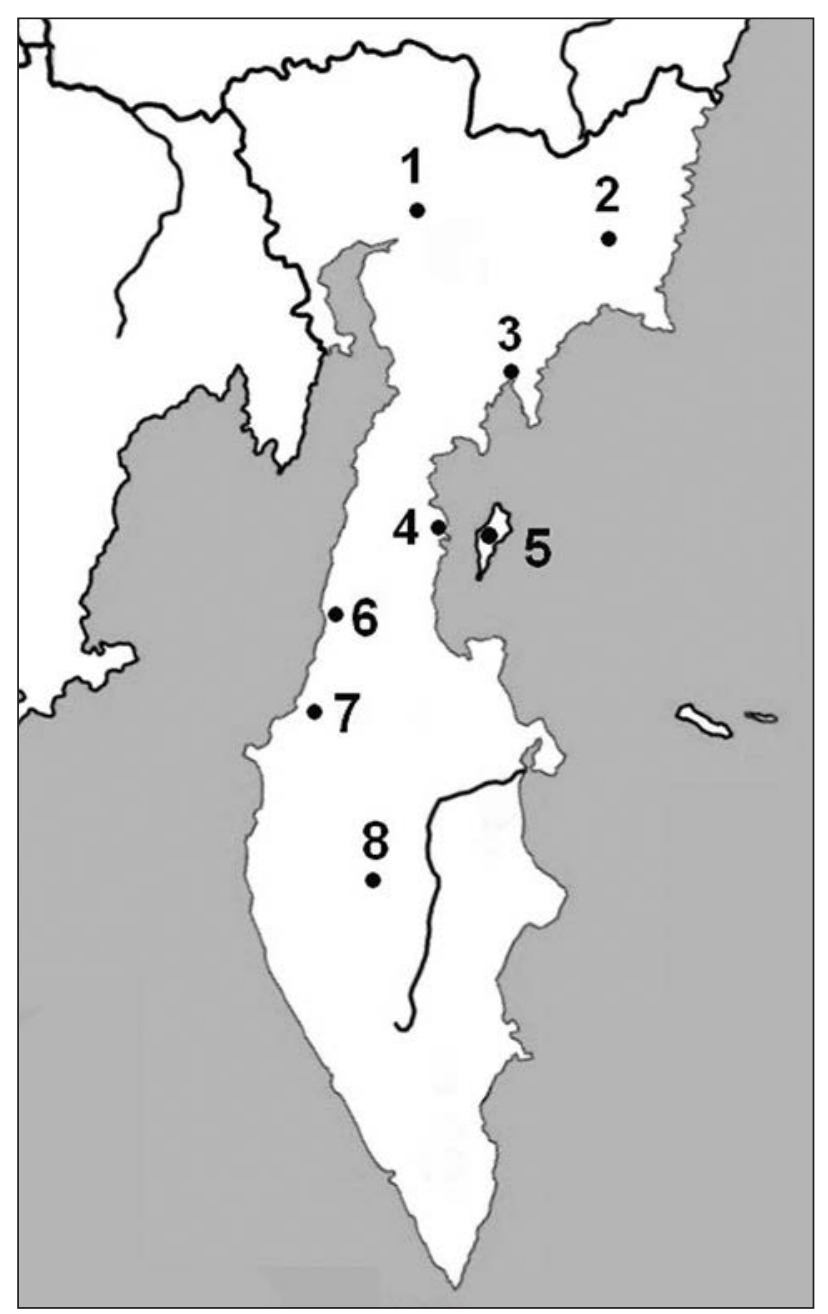

Рисунок. Пункты сборов на территории Камчатки: 1 - пос. Каменское; 2 - пос. Ачайваям; 3 - пос. Тиличики; 4 - пос. Оссора; 5 - о. Карагинский; 6 - пос. Палана; 7 - пос. Тигиль; 8 - пос. Эссо

Figure. Collecting localities in Kamchatka: 1 - settlement of Kamenskoye; 2 - settlement of Achayvayam; 3 - settlement of Tilichiki; 4 - settlement of Ossora; 5 - Karaginskiy Island; 6 - settlement of Palana; 7 - settlement of Tigil'; 8 - settlement of Esso по распространению (Herman, 2001; Schülke, Smetana, 2015). Внутри подсемейств таксоны расположены в алфавитном порядке. После видового названия указаны: название ареала с учетом региональной и зональной составляющих по классификации Городкова (1984); общее распространение; субрегионы Северо-Востока Азии, где вид известен; биотопическая приуроченность; информация о материале.

Часто встречающийся в тексте термин «ст $a$ рика» означает старую, прошлогоднюю траву, часто сухую сверху и влажную, преющую внизу.

Семейство Staphylinidae Latreille, 1802

Подсемейство Steninae MacLeay, 1825

Stenus (Metastenus) auriger Eppelsheim, 1893. Восточнопалеарктический температный вид. Обитает в Азии (северный и северо-восточный Китай, Монголия, Северная Корея); в том числе в восточной Сибири и на Дальнем Востоке России (Herman, 2001: 2075; Schülke, Smetana, 2015: 807). На Северо-Востоке Азии отмечен в Магаданской области (Ryabukhin, 1999: 50 (как $S$. (Hemistenus) auriger) и на Камчатке (Bernhauer, 1925: 2; Лобкова, Семенов, 2012: 96).

Встречается в почвенной подстилке лесов и кустарников, напочвенном покрове тундр, на открытых пространствах под различными укрытиями на почве. Иногда - на растительности.

Материал. Карагинский $\mathrm{p}-\mathrm{H}$, окрестности пос. Оссора. 20.07.2008. Мохово-кустарничковая тундра на террасе. Иногда под кустами багульника и голубики подушки сфагнума. В напочвенном покрове. - 6 экз. А. С. Рябухин. 28.07.2008. Низинная кустарничково-сфагновая тундра у озера. В подстилке, во мху. - 5 экз. А. С. Рябухин.

Тигильский $\mathrm{p}-\mathrm{H}$, окрестности пос. Палана. 20.07.2009. Низинная кустарничково-травяномоховая крупнобугристая тундра. Местами, на возвышенных участках, - подушки лишайников. В напочвенном покрове. - 3 экз. А. С. Рябухин. Окрестности пос. Тигиль. 27-28.07.2010. Надпойменная терраса p. Тигиль. Низинная влажная разнотравно-осоковая тундра, закустаренная редкими кустами ивы, ольхи и березы. Низкие осоковые и злаковые кочки. Довольно много мхов, иногда - старики. В напочвенном покрове, во мху. -4 экз. А. С. Рябухин.

Пенжинский р-н, окрестности пос. Каменское. 15.07.2011. Низинная кустарничковая тундра. Редкие кусты ольхи, ивы, березы Миддендорфа. Осоковые кочки, бугры, подушки мхов. В напочвенном покрове, во мху. - 4 экз. А. С. Рябухин. 19.07.2011. Там же. -5 экз. А. С. Рябухин.

Stenus (Metastenus) pubescens fraternus (Casey, 1884). Голарктический бореальный подвид S. (M.) pubescens Stephens, 1833. Распространен в Азии (Казахстан, Монголия, северо-восточный 
Китай, Япония (о. Хоккайдо) и Северной Америке (Канада, США). В России встречается в восточной Сибири и на Дальнем Востоке (Herman, 2001: 2355 (как S. pubescens); Schülke, Smetana, 2015: 837). На Северо-Востоке Азии отмечен в Магаданской области и на Камчатке (Bernhauer, 1925: 2 (как S. pubescens Steph.); Ryabukhin, 1999: 50 (как $S$. (Hemistenus) sandersonianus); Лобкова, Семенов (2012: 96).

Обитает по берегам ручьев, на болотах, лугах, в напочвенном покрове тундр. Иногда - на растительности.

Материал. Тигильский $\mathrm{p}-\mathrm{H}$, окрестности пос. Палана. 8.08.2009. Низинная кустарничковотравяно-моховая крупнобугристая тундра. Местами, на возвышенных участках - подушки лишайников. В напочвенном покрове. -4 экз. А. С. Рябухин.

Пенжинский р-н, окрестности пос. Каменское. 10.07.2011. Низинная мохово-кустарничковая тундра, слабо закустаренная ольхой. Единичные кусты березы Миддендорфа, ивы. Небольшие осоковые кочки. Местами куртины мхов. Пересыхающие или уже практически высохшие небольшие болотца. В напочвенном покрове. 5 экз. А. С. Рябухин. 20.07.2011. Там же. Низинная кустарничковая тундра. «Ленточное» пышное злаковое высокотравье по руслу практически пересохшего и заросшего ручейка. Мощная многолетняя старика. От сухой сверху до мокрой, гниющей внизу. В ее среднем и нижнем слоях. 3 экз. А. С. Рябухин.

Stenus (s. str.) bilineatus J. Sahlberg, 1871. Голарктический арктобореальный вид. Распространен в северной Европе (Финляндия, Норвегия, Швеция) и Северной Америке (Канада, США). В России обитает в северных районах европейской части, в Сибири и на Дальнем Востоке (Herman, 2001: 2088; Schülke, Smetana, 2015: 808). На Северо-Востоке Азии известен из Магаданской области и с Камчатки (Ryabukhin, 1999: 43).

Обитает во влажных биотопах, по берегам стоячих и медленнотекущих водоемов, в напочвенном покрове тундр.

Материал. Тигильский $\mathrm{p}-\mathrm{H}$, окрестности пос. Тигиль. 25.07.2010. Надпойменная терраca p. Тигиль. Низинная влажная разнотравноосоковая тундра, закустаренная редкими кустами ивы, ольхи и березы. Низкие осоковые и злаковые кочки. Довольно много мхов, иногда старики. В напочвенном покрове, во мху. -8 экз. А. С. Рябухин. 26.07.2010. Там же. Участок с отдельными куртинами карликовой березки и более густыми, но низкими кустами ивы. Довольно много клюквы, мелких вересковых и гречишных. В подстилке, во мху. - 9 экз. А. С. Рябухин.

Пенжинский р-н, окрестности пос. Каменское. 16.07.2011. Низинная мохово-кустарничковая тундра. Влажный участок, закустаренный ольхой, ивой, березой Миддендорфа. Небольшие, почти заросшие болотца с осокой и пышными мхами. В подстилке, во мху. - 2 экз. А. С. Рябухин.

Олюторский р-н, окрестности пос. Тиличики. 09.07.2012. Низинная кустарничковая тундра, закустаренная ольхой, березой Миддендорфа. Редкие низкие осоковые и злаковые кочки. Куртины мхов. В подстилке. - 3 экз. А. С. Рябухин.

Stenus (s. str.) clavicornis (Scopoli, 1763). Голарктический арктотемператный вид. Широко распространен в Европе и Азии. Интродуцирован в Северную Америку (Канаду и США). В России встречается в европейской части, в Сибири и на Дальнем Востоке (Herman, 2001: 2126; Schülke, Smetana, 2015: 812). На Северо-Востоке Азии отмечен в Магаданской области и на Камчатке (Ryabukhin, 1999: 43; Лобкова, Семенов, 2012: 95).

Обитает во влажных биотопах, по берегам водоемов, на влажных обочинах дорог, в напочвенном покрове тундр. Медведев, Чикилевская (1977: 56), Медведев и др. (1980: 551) отмечают его нахождение в гнездах грызунов. Лобкова, Семенов (2012: 95) сообщают о находке одного экземпляра этого вида в прошлогоднем гнезде пеночки-таловки.

Материал. Карагинский p-н, окрестности пос. Оссора. 28.07.2008. Низинная кустарничково-сфагновая тундра у озера. Во мху. - 3 экз. А. С. Рябухин.

Тигильский р-н, окрестности пос. Тигиль. 27-28.07.2010. Надпойменная терраса р. Тигиль. Низинная влажная разнотравно-осоковая тундра, закустаренная редкими кустами ивы, ольхи и березы. Низкие осоковые и злаковые кочки. Довольно много мхов, иногда - старики. В подстилке, во мху. -3 экз. А. С. Рябухин.

Пенжинский р-н, окрестности пос. Каменское. 18.07.2011. Низинная кустарничковая тундра, закустаренная ольхой. Единичные кусты березы Миддендорфа, ивы. Небольшие осоковые кочки. Довольно много мхов. Пересыхающие или уже практически высохшие небольшие болотца. В подстилке, во мху. - 3 экз. А. С. Рябухин.

Олюторский р-н, окрестности пос. Ачайваям. 10.07.2013. Низинная мохово-кустарничковая тундра. Редкие низкие осоковые кочки, бугры. В напочвенном покрове, во мху. - 4 экз. А. С. Рябухин.

Stenus (s. str.) comma LeConte, 1863. Голарктический субарктотемператный вид. Широко распространен в Европе, Азии и Северной Америке (Канаде и США). В России встречается в европейской части, в Сибири и на Дальнем Востоке (Herman, 2001: 2135; Schülke, Smetana, 2015: 813 (как S. (s. str.) comma сотma). На Северо-Востоке Азии отмечен в Магаданской области, на Чукотке и Камчатке (Ryabukhin, 1999: 44; Лобкова, Ceменов, 2012: 95). 
Обитает по берегам стоячих и проточных водоемов, на морских побережьях, в напочвенном покрове тундр, на поверхности почвы, в почвенной подстилке. Иногда на травяной и кустарниковой растительности.

Материал. Карагинский p-н, окрестности пос. Оссора. 28.07.2008. Низинная кустарничково-сфагновая тундра у озера. В напочвенном покрове, во мху. -6 экз. А. С. Рябухин.

Тигильский p-н, окрестности пос. Тигиль. 25.07.2010. Надпойменная терраса р. Тигиль. Низинная влажная разнотравно-осоковая тундра, закустаренная редкими кустами ивы, ольхи и березы. Низкие осоковые и злаковые кочки. Довольно много мхов, местами - старики. В напочвенном покрове, во мху. -8 экз. А. С. Рябухин. 26.07.2010. Там же. Участок с отдельными куртинами карликовой березки и более густыми, но низкими кустами ивы. Довольно много клюквы, мелких вересковых и гречишных. - 4 экз. А. С. Рябухин.

Пенжинский р-н, окрестности пос. Каменское. 16.07.2011. Низинная мохово-кустарничковая тундра. Влажный участок, закустаренный ольхой, ивой, березой Миддендорфа. Осоковые кочки, бугры, мхи. Небольшие, почти заросшие болотца с осокой и пышными мхами. В подстилке. -1 экз. А. С. Рябухин. 31.07.2011. Там же. Западный шлейф сопки. На фоне кустарничковой тундры молодая, довольно редкая поросль ольхи и ивы. Осоковые кочки, злаки, довольно много мхов. Между кочками - старика, листовой опад от кустарников. В подстилке, во мху. - 2 экз. А. С. Рябухин.

Олюторский р-н, окрестности пос. Тиличики. 25.07.2012. Очень пологий склон морской террасы. Низинная мохово-кустарничковая тундра, закустаренная ивой, березой Миддендорфа, ольхой. Много зеленых мхов, сфагнума. Местами куртины лишайников. В подстилке, во мху. - 4 экз. А. С. Рябухин.

Stenus (s. str.) fasciculatus J. Sahlberg, 1871. Голарктический арктобореальный вид. Распространен в северной Европе (Финляндия, Норвегия, Швеция), Азии (северный Китай) и Северной Америке (Канада и США). В России обитает в Сибири и на Дальнем Востоке (Herman, 2001: 2174; Schülke, Smetana, 2015: 816). На СевероВостоке Азии найден в Магаданской области и на Чукотке (Ryabukhin, 1999: 44). Для Камчатки приводился Naomi et al. (2000: 108) и Лобковой, Семеновым (2012: 95).

Обитает по берегам водоемов, у наледей, в тундрах, иногда - на растительности.

Материал. Тигильский p-н, окрестности пос. Тигиль. 27-28.07.2010. Надпойменная терpaca p. Тигиль. Низинная влажная разнотравноосоковая тундра, закустаренная редкими кустами ивы, ольхи и березы. Низкие осоковые и злаковые кочки. Довольно много мхов, местами - ст $a$ рики. В подстилке. -4 экз. А. С. Рябухин.

Пенжинский p-н, окрестности пос. Каменское. 21.07.2011. Низинная кустарничковая тундра. Влажный участок, закустаренный ольхой, ивой, березой Миддендорфа. Осоковые кочки, бугры. Небольшие, почти заросшие болотца с осокой и пышными мхами. В подстилке, во мху. -5 экз. А. С. Рябухин.

Олюторский р-н, окрестности пос. Ачайваям. 14-15.07.2013. Низинная мохово-кустарничковая тундра. Редкие низкие осоковые кочки. Более влажный участок с буграми и густыми зарослями карликовой березки и ивы. В напочвенном покрове, во мху. - 3 экз. А. С. Рябухин. 16.07.2013. Там же. -1 экз. А. С. Рябухин.

Stenus (s. str.) juno (Paykull, 1789). Голарктический субарктотемператный вид. Имеет обширный ареал, распространен в Европе, Северной Африке (Алжир) и Азии (Турция, Казахстан, северный и северо-восточный Китай, Япония). Интродуцирован в Северной Америке (Канада и США). В России встречается в европейской части, в Сибири и на Дальнем Востоке (Herman, 2001: 2240; Schülke, Smetana, 2015: 825). На Северо-Востоке Азии обнаружен в Магаданской области и на Камчатке (Ryabukhin, 1999: 42). Якобсон (1905-1915: 479) приводит этот вид для Чукотки (о. Врангеля). Сажнев (2018: 21) отмечает его нахождение на Командорах (о. Беринга).

Обитает во влажных биотопах, по берегам стоячих и медленнотекущих водоемов, на болотах, в тундре.

Материал. Тигильский $\mathrm{p}-\mathrm{H}$, окрестности пос. Тигиль. 27-28.07.2010. Надпойменная терpaca p. Тигиль. Низинная влажная разнотравноосоковая тундра, закустаренная редкими кустами ивы, ольхи и березы. Низкие осоковые и злаковые кочки. Довольно много мхов, местами - ст $a-$ рики. В подстилке. -5 экз. А. С. Рябухин.

Пенжинский р-н, окрестности пос. Каменское. 16.07.2011. Низинная мохово-кустарничковая тундра. Влажный участок, закустаренный ольхой, ивой, березой Миддендорфа. Осоковые кочки, бугры. Небольшие, почти заросшие болотца с осокой и пышными мхами. В подстилке. - 2 экз. А. С. Рябухин.

Олюторский р-н, окрестности пос. Ачайваям. 25-29.07.2013. Низинная мохово-кустарничковая тундра. Редкие низкие осоковые кочки, бугры. Верхний слой напочвенного покрова совершенно сухой. Только в локальных понижениях влажные подушки мхов. -4 экз. А. С. Рябухин.

Подсемейство Euaesthetinae Thomson, 1859

Euaesthetus ruficollis Motschulsky, 1860. Bocточнопалеарктический бореальный вид. Распро- 
странен в восточной Сибири и на Дальнем Востоке России; в Монголии (Herman, 2001: 1849; Schülke, Smetana, 2015: 853). На Северо-Востоке Азии встречается в Магаданской области и на Камчатке (Ryabukhin, 1999: 42).

Обитает на болотах, заболоченных берегах водоемов во мху, влажной подстилке, в лесах в подушках сфагнума, в напочвенном покрове тундр. Изредка - на лугах среди корней травы, кустарников, под камнями.

Материал. Тигильский $\mathrm{p}-\mathrm{H}$, окрестности пос. Тигиль. 25-28.07.2010. Надпойменная терpaca p. Тигиль. Разнотравно-осоковая влажная низинная тундра, закустаренная редкими кустами ивы, ольхи и березы. Низкие осоковые и злаковые кочки. Довольно много мхов, иногда - ст $a$ рики. В напочвенном покрове, во мху. - 23 экз. А. С. Рябухин. 26.07.2010. Там же. Участок с отдельными куртинами карликовой березки и более густыми, но низкими кустами ивы. Довольно много клюквы, мелких вересковых и гречишных. В подстилке, во мху. - 15 экз. А. С. Рябухин.

Пенжинский p-н, окрестности пос. Каменское. 10-19.07.2011. Низинная кустарничковая тундра, слабо закустаренная ольхой, березой Миддендорфа, ивами. Местами куртины мхов. Небольшие осоковые кочки. Пересыхающие или уже практически высохшие небольшие болотца. В напочвенном покрове, во мху. - 20 экз. А. С. Рябухин. 21.07.2011. Там же. Низинная кустарничковая тундра. Осоковые кочки, бугры. Более влажный участок, закустаренный ольхой, ивой, березой Миддендорфа. Небольшие, почти заросшие болотца с осокой и пышными мхами. - 16 экз. А. С. Рябухин. 31.07.2011. Там же. Западный шлейф сопки. На фоне кустарничковой тундры молодая, редкая поросль ольхи и ивы. Осоковые кочки, злаки, довольно много мхов. Между кочками - старика, листовой опад от кустарников. 10 экз. А. С. Рябухин.

Олюторский р-н, окрестности пос. Тиличики. 09.07.2012. Низинная кустарничковая тундра, закустаренная ольхой, березой Миддендорфа. В напочвенном покрове, во мху. - 2 экз. А. С. Рябухин. 25.07.2012. Там же. Очень пологий восточный склон приморской террасы. Низинная кустарничковая тундра, закустаренная ивой, березой Миддендорфа, ольхой. Много зеленых мхов, сфагнума. Местами куртины лишайников. -8 экз. А. С. Рябухин. Окрестности пос. Ачайваям. 10.07.2013. Низинная моховокустарничковая тундра. В напочвенном покрове. -3 экз. А. С. Рябухин. 16.07.2013. Там же. 9 экз. А. С. Рябухин. 25-29.07.2013. Низинная кустарничковая тундра. Верхний слой напочвенного покрова совершенно сухой. Только в локальных понижениях влажные подушки мхов. 8 экз. А. С. Рябухин.
Подсемейство Paederinae Fleming, 1821

Lathrobium (s. str.) brunnipes (Fabricius, 1793). Палеарктический температный вид. Широко распространен в Европе. В Азии известен из Турции, Казахстана, Киргизии и Монголии. В России встречается в европейской части, в Сибири и на Дальнем Востоке (Schülke, Smetana, 2015: 946). На Северо-Востоке Азии обнаружен в Магаданской области (Ryabukhin, 1999: 52) и на Камчатке.

Обитает во влажной почвенной подстилке пойменных лесов, кустарников, под корой и в толще влажной, трухлявой древесины поваленных деревьев, на болотах во мху, по берегам водоемов во влажных выбросах.

Материал. Тигильский $\mathrm{p}-\mathrm{H}$, окрестности пос. Тигиль. 28.07.2010. Надпойменная терраса p. Тигиль. Разнотравно-осоковая влажная низинная тундра, закустаренная редкими кустами ивы, ольхи и березы. Низкие осоковые и злаковые кочки. Довольно много мхов, иногда - старики. В напочвенном покрове. - 1 экз. А. С. Рябухин.

Lathrobium (s. str.) kamenum Ryabukhin, 2018. Вид описан с Камчатки. Пока известен только из типового местообитания.

Материал. Пенжинский p-н, окрестности пос. Каменское. 11-19.07.2011. Низинная кустарничковая тундра. Кусты ольхи, ивы, березы Миддендорфа. Осоковые кочки, бугры, мхи. Местами небольшие, почти заросшие болотца с осокой и пышными мхами. В подстилке, в старике между кочками. - 15 экз. А. С. Рябухин. 31.07.2011. Там же. Западный шлейф сопки. На фоне кустарничковой тундры молодая, довольно редкая поросль ольхи и ивы. Осоковые кочки, злаки, бугры, довольно много мхов. Между кочками - старика, листовой опад от кустарников. В подстилке, во мху. -8 экз. А. С. Рябухин.

Lathrobium (s. str.) palanum Ryabukhin, 2015. Вид описан с Камчатки. Пока известен только из типового местообитания.

Материал. Тигильский $\mathrm{p}-\mathrm{H}$, окрестности пос. Палана. 10.07-4.08.2009. Южные и югозападные склоны сопок. Леса из каменной березы с редкими ольхами, кустами кедрового стланика и разнотравно-злаково-осоковым травяным покровом. В подстилке. - 15 экз. А. С. Рябухин. 8.08.2009. Там же. Низинная кустарничковотравяно-моховая крупнобугристая тундра. Местами, на возвышенных участках - подушки лишайников. Два экземпляра собраны А. С. Рябухиным на боковой части бугра, поросшего карликовой березкой, в подстилке и листовом опаде.

Tetartopeus niger (LeConte, 1863). Дальневосточно-неарктический бореальный вид. Распространен в Азии (российский Дальний Восток, Япония) и в Северной Америке (Канада, США) Schülke, Smetana (2015: 969). На Северо-Востоке 
Азии найден в Магаданской области и на Камчатке (Ryabukhin, 1999: 55 (как T. nigrus).

Обитает на мокрых берегах болот, ручьев во мху, в гниющих растительных остатках, среди корней болотной растительности; в мокрой почвенной подстилке прибрежных зарослей.

Материал. Тигильский р-н, окрестности пос. Тигиль. 25-8.07.2010. Надпойменная терраса p. Тигиль. Влажная разнотравно-осоковая низинная тундра, закустаренная редкими кустами ивы, ольхи и березы. Низкие осоковые и злаковые кочки. Довольно много мхов, иногда - старики. В подстилке. -8 экз. А. С. Рябухин.

Пенжинский р-н, окрестности пос. Каменское. 16-21.07.2011. Низинная кустарничковая тундра. Осоковые кочки, бугры, мхи. Более влажный участок, закустаренный ольхой, ивой, березой Миддендорфа. Небольшие, почти заросшие болотца с осокой и пышными мхами. В подстилке, во мху. -25 экз. А. С. Рябухин. 31.07.2011. Там же. Западный шлейф сопки. Низинная кустарничковая тундра с редкой порослью ольхи и ивы. Осоковые кочки, злаки, довольно много мхов. Между кочками - старика, листовой опад от кустарников. В подстилке, во мху. - 13 экз. А. С. Рябухин.

Олюторский р-н, окрестности пос. Тиличики. 25.07.2012. Очень пологий восточный склон морской террасы. Низинная тундра, закустаренная ивой, березой Миддендорфа, ольхой. Много зеленых мхов, сфагнума. Местами куртины лишайников. Во мху. - 1 экз. А. С. Рябухин.

Подсемейство Staphylininae Latreille, 1802

Creophilus maxillosus villosus (Gravenhorst, 1802). Подвид мультирегионального C. maxillosus (Linnaeus, 1758). Распространен на российском Дальнем Востоке, в Неарктической и Неотропической областях (Schülke, Smetana, 2015: 1082). На Северо-Востоке Азии отмечен на Командорских островах (Ryabukhin, 1999: 68; Сажнев, 2018: 21).

Обитает на падали, реже - в экскрементах, разлагающихся растительных остатках, под камнями и другими укрытиями на почве.

В наших сборах отсутствует. Сажнев (2018: 21) указывает на его спорадическое нахождение в тундре на о. Беринга.

Philonthus (s. str.) ebeninus (Gravenhorst, 1802). Палеарктический субарктотемператный вид. Широко распространен в Европе и Азии, отмечен в Северной Африке (Алжир). В России встречается в европейской части, в Сибири и на Дальнем Востоке (Herman, 2001: 2814; Schülke, Smetana, 2015: 1040).

В наших сборах отсутствует. Лобкова, Семенов (2012: 100) отмечают его нахождение в горных кустарничковых тундрах Кроноцкого заповедника.
Philonthus (s. str.) parvicornis (Gravenhorst, 1802). Мультирегиональный вид. Имеет обширный ареал, распространен в Европе, Северной Африке, Азии, а также в Ориентальной (ИндоМалайской) области. В России встречается в европейской части, в Сибири и на Дальнем Востоке (Herman, 2001: 2906; Schülke, Smetana, 2015: 1046). На Северо-Востоке Азии отмечен Bernhauer (1925: 2 (как Ph. agilis Gr.) на Камчатке.

Материал. Карагинский р-н, о. Карагинский. Устье р. Гнумваям. 21.07.2008. Морская терраса (высота 5 м н. у. м.). Кустарничковая тундра (березки, голубика, вороника, морошка) с единичными кустами кедрового стланика. - 1 экз. О. А. Хрулева.

Philonthus (s. str.) quisquiliarius (Gyllenhal, 1810). Мультирегиональный вид. Имеет обширный ареал, распространен в Европе, Северной Африке, Азии, а также в Афротропической области. В России встречается в европейской части, Сибири и на Дальнем Востоке (Herman, 2001: 2929; Schülke, Smetana, 2015: 1047 (как Ph. (s. str.) quisquiliarius quisquiliarius). На Северо-Востоке Азии отмечен Bernhauer (1925: 2) на Камчатке.

Материал. Тигильский р-н, окрестности пос. Тигиль. 25.07.2010. Надпойменная терраса р. Тигиль. Разнотравно-осоковая влажная низинная тундра, закустаренная редкими кустами ивы, ольхи и березы. Низкие осоковые и злаковые кочки. Довольно много мхов, иногда - старики. В напочвенном покрове. -1 экз. А. С. Рябухин.

Philonthus (s. str.) rotundicollis (Ménétriès, 1832). Палеарктический субарктотемператный вид. Широко распространен в Европе и Азии. В России встречается в европейской части, в Сибири и на Дальнем Востоке (Herman, 2001: 2939; Schülke, Smetana, 2015: 1048). На СевероВостоке Азии обнаружен в Магаданской области и на Камчатке (Bernhauer, 1925: 2; Ryabukhin, 1999: 62; Лобкова, Семенов, 2012: 97).

Обитает в почвенной подстилке, во мху, по берегам водоемов, в разлагающихся растительных остатках, изредка - на падали.

Материал. Олюторский $\mathrm{p}-\mathrm{H}$, окрестности пос. Ачайваям. 27.07.2013. Низинная кустарничковая тундра. Верхний слой напочвенного покрова совершенно сухой. Только в локальных понижениях влажные подушки мхов. Во мху. - 3 экз. А. С. Рябухин.

Quedius (Distichalius) kamchaticus Smetana, 1976. Вид описан с Камчатки. Также известен с о. Хоккайдо в Японии (Schülke, Smetana, 2015: 1057).

В наших сборах отсутствует. Лобкова, Семенов (2012: 100) отмечают его нахождение в горных кустарничковых тундрах Кроноцкого заповедника. 
Quedius (Microsaurus) mesomelinus (Marsham, 1802). Мультирегиональный вид. Имеет обширный ареал, распространен в Европе и Азии, отмечен в Перу и на о-вах Тристан да Кунья. Интродуцирован в Неарктическую, Неотропическую и Австралийскую области. В России распространен в европейской части, Сибири и на Дальнем Востоке (Herman, 2001: 3199 (как Q. mesomelinus); Schülke, Smetana, 2015: 1063 (как Q. (M.) mesomelinus mesomelinus). На СевероВостоке Азии ранее отмечался в Магаданской области и на Камчатке (Ryabukhin, 1999: 72).

Обитает в лесной подстилке, во мху, в напочвенном покрове тундр, под различными предметами на почве, в речных выбросах, прелой траве, в поваленных трухлявых деревьях, дуплах, пещерах, норах различных млекопитающих, гнилых грибах, пищевых отбросах, в экскрементах, на падали.

Материал. Быстринский $\mathrm{p}-\mathrm{H}$, окрестности пос. Эссо. 16.06.1989. Горное плато. Гольцовый пояс. Травяно-мохово-кустарничковая тундра. В толще напочвенного покрова, под камнями. 1 экз. А. С. Рябухин.

Quedius (Raphirus) cf. fellmani (Zetterstedt, 1838). Очень похож и, вероятно, принадлежит голарктическому арктобореальному $Q$. (R.) $\mathrm{fel}$ Imani (Zetterstedt, 1838), распространенному в северной Европе, Азии (Монголия), Канаде и США. В России обитает на севере европейской части, в Сибири и на Дальнем Востоке (Herman, 2001: 3146; Schülke, Smetana, 2015: 1071). На СевероВостоке Азии отмечен в Магаданской области, на Чукотке и Камчатке (Ryabukhin, 1999: 74).

Обитает в почвенной подстилке лесов и кустарников, на болотах, во мху, в напочвенном покрове тундр, по берегам водоемов среди выбросов, в разлагающихся растительных остатках, под различными предметами на почве на лугах, обочинах грунтовых дорог. Smetana (1971: 235) указывает на приуроченность этого вида к влажным биотопам, при этом не исключая его нахождения в сухих.

Quedius (Raphirus) cf. fulvicollis (Stephens, 1833). Очень похож и, вероятно, принадлежит голарктическому арктобореальному $Q$. (R.) fulvicollis (Stephens, 1833), который широко pacпространен в Европе, Канаде и США. Отмечен в Азии (Кыргызстан). В России обитает на севере европейской части, в Сибири и на Дальнем Востоке (Herman, 2001: 3159; Schülke, Smetana, 2015: 1071). Для Северо-Востока Азии ранее приводился для Магаданской области, Чукотки, Камчатки и Командорских островов (Ryabukhin, 1999: 74).

Обитает во влажных биотопах: в почвенной подстилке пойменных лесов и кустарников, во мху, на болотах, в напочвенном покрове тундр, разлагающихся растительных остатках, среди выбросов по берегам водоемов.
Quedius (Raphirus) cf. sublimbatus Mäklin, 1853. Очень похож и, вероятно, принадлежит голарктическому арктобореальному $Q$. (R.) sublimbatus Mäklin, 1853, распространенному в северной Европе, Азии (Монголия), Канаде и США. В России обитает на севере европейской части, в Сибири и на Дальнем Востоке (Herman, 2001: 3276; Schülke, Smetana, 2015: 1078). На СевероВостоке Азии отмечен в Магаданской области, на Чукотке, Камчатке и Командорских островах (Ryabukhin, 1999: 75).

Обитает во влажных биотопах: на болотах во мху, в напочвенном покрове тундр, в подстилке пойменных лесов и кустарников, по берегам водоемов среди выбросов, в разлагающихся растительных остатках.

\section{БЛАГОДАРНОСТИ}

Моя искренняя благодарность О. А. Хрулевой (Институт проблем экологии и эволюции РАН, Москва) за сбор материала на о. Карагинский.

Работа выполнена при финансовой поддержке ДВО РАН (гранты № 04-3-Е-06-018, 05-III-E-06-30, 06-ІІІ-Д-06-246, 08-ІІІ-Д-06-058, 10-ІІІ-Д-06-020, 12 III-L-06-021, 13-III-L-06-003).

\section{ЛИТЕРАТУРА}

Городков К. Б. Типы ареалов насекомых тундры и лесных зон европейской части СССР // Ареалы насекомых европейской части СССР. Атлас. Карты 179221. Ленинград : Наука, 1984. С. 3-20.

Лобкова Л. Е., Семенов В. Б. Стафилиниды (Coleoptera, Staphylinidae) Кроноцкого заповедника и сопредельных территорий Камчатки // Труды Кроноцкого государственного природного биосферного заповедника. Петропавловск-Камчатский : Камчатпресс, 2012. Вып. 2. С. 85-102.

Медведев С. И., Чикилевская И. В. Зоогеографическая характеристика фауны жуков (Coleoptera) из гнезд грызунов Белорусского Полесья // Энтомологическое обозрение. 1977. Т. 56, № 1. С. 53-59.

Медведев С. И., Мищенко А. А., Петренко А. А. Эколого-географический обзор стафилинид (Coleoptera, Staphylinidae) песчаных почв Харьковской области // Там же. 1980. Т. 59, № 3. С. 550-555.

Рябухин A. C. Материалы к фауне стафилинид (Coleoptera: Staphylinidae) тундр Камчатки ( подсемейства Omaliinae, Proteininae, Pselaphinae, Tachyporinae и Oxytelinae) // Вестник Северо-Восточного научного центра ДВО РАН. 2020. № 2. С. 59-68.

Сажнев A. C. Материалы к фауне стафилинид (Coleoptera: Staphylinidae) Командорских островов (Камчатский край, Россия) // Кавказский энтомологический бюллетень. 2018. Т. 14. Вып. 1. С. 19-23.

Якобсон Г. Г. Жуки России и Западной Европы. Санкт-Петербург : Изд-во А. Ф. Девриена, 1905-1915. $1024 \mathrm{c}$.

Bernhauer M. Entomologische Ergebnisse der schwedischen Kamtchatka-Expedition 1920-1922. 8. Staphylinidae // Arkiv för Zoologi. 1925. Bd. 18 B, No. 4. S. 1-2.

Herman L. H. Catalog of the Staphylinidae (Insecta: Coleoptera). 1785 to the end of the second Millennium. 
Parts I-VII. Bulletin of the American Museum of Natural History. New York, 2001. No. 265. 4218 p.

Naomi S.-I., Kuranishi R. B., Saito A., Maruyama M. A list of the Family Staphylinidae (Insecta: Coleoptera) collected during the biological expedition to the Kamchatka Peninsula and the North Kuril Islands in 1996 and 1997 // Results of recent research on Northeast Asian Biota. Natural History Museum and Institute, Chiba. Natural History Research, Special Issue, 2000. No. 7. P. 101-111.

Ryabukhin A. S. A catalogue of rove beetles (Coleoptera: Staphylinidae exclusive of Aleocharinae) of the
Northeast of Asia. Sofia; Moscow : Pensoft Publishers, 1999. $140 \mathrm{p}$.

Schülke M., Smetana A. Family Staphylinidae Latreille, 1802 // Catalogue of Palaearctic Coleoptera. Vol. 2/1. Hydrophiloidea - Staphylinoidea / eds. I. Löbl, D. Löbl. Leiden ; Boston : Brill, 2015. P. 304-1134.

Smetana A. Revision of the tribe Quediini of America north of Mexico (Coleoptera, Staphylinidae) // Memoirs of the entomological society of Canada. 1971. No. 79.303 p.

Поступила в редакцию 12.10.2020 г.

Поступила после доработки 28.10.2020 2.

\title{
MATERIALS TO THE FAUNA OF ROVE BEETLES (COLEOPTERA: STAPHYLINIDAE) OF KAMCHATKA TUNDRAS (Subfamilies STENINAE, EUAESTHETINAE, PAEDERINAE AND STAPHYLININAE)
}

\author{
A. S. Ryabukhin \\ Institute of Biological Problems of the North, FEB RAS, Magadan
}

\begin{abstract}
The article presents results of summarizing publications and studying the material collected in various districts of Kamchatka. 22 species of rove beetles from 7 genera, belonging to the Steninae, Euaesthetinae, Paederinae, and Staphylininae subfamilies, are recorded for the Kamchatka tundra fauna. Species identity of Quedius (Raphirus) cf. fellmani (Zetterstedt, 1838), Q. (R.) cf. fulvicollis (Stephens, 1833), and Q. (R.) cf. sublimbatus Mäklin, 1853 from the subfamily Staphylininae requires updating. An annotated list has been compiled. Collecting localities are mapped.
\end{abstract}

\section{Keywords: Coleoptera, Staphylinidae, Kamchatka, fauna, tundras.}

\section{REFERENCES}

Bernhauer, M., 1925. Entomologische Ergebnisse der Schwedischen Kamtchatka-Expedition 1920-1922. 8. Staphylinidae, Arkiv för Zoologi. 18 (4), 1-2.

Gorodkov, K. B., 1984. Types of Insect Ranges in the Tundra and Forests Zones of the European Part of USSR, Areals of Insects in the European Part of the USSR. Atlas. Maps 179-221. Leningrad, Nauka, 3-20 [In Russian].

Herman, L. H., 2001. Catalog of the Staphylinidae (Insecta: Coleoptera). 1785 to the End of the Second Millennium. Parts I-VII. Bulletin of the American Museum of Natural History. New York, 265.

Lobkova, L. E., Semenov V. B., 2012. Staphylinides (Coleoptera, Staphylinidae) in the Kronotsky Reserve and the Adjacent Territories of Kamchatka, Trudy Kronockogo Gosudarstvennogo Prirodnogo Biosfernogo Zapovednika. Petropavlovsk-Kamchatsky, Kamchatpress. 2, 85102 [In Russian].

Medvedev, S. I., Chikilevskaya, I. V., 1977. Zoogeographical Characteristics of the Beetle Fauna (Coleoptera) from the Nests of Rodents in Byelorussian Polesye, Entomological Review. 56, 1, 53-59 [In Russian].

Medvedev, S. I., Mishchenko, A. A., Petrenko, A. A., 1980. An Ecogeographical Review of Staphylinids of Sand Soils in the Khar'kov Area (Coleoptera, Staphylinidae), Ibid. 59, 3, 550-555 [In Russian].

Naomi, S.-I., Kuranishi, R. B., Saito, A., Maruya$m a, M ., 2000$. A List of the Family Staphylinidae (Insec- ta: Coleoptera) Collected during the Biological Expedition to the Kamchatka Peninsula and the North Kuril Islands in 1996 and 1997. Results of Recent Research on Northeast Asian Biota, Natural History Museum and Institute, Chiba, Natural History Research, Special Issue. 7, 101-111.

Ryabukhin, A. S., 1999. A Catalogue of Rove Beetles (Coleoptera: Staphylinidae Exclusive of Aleocharinae) of the Northeast of Asia, Sofia; Moscow, Pensoft Publishers.

Ryabukhin, A. S., 2020. Materials on the Fauna of Rove Beetles (Coleoptera: Staphylinidae) of the Kamchatka Tundras (Subfamilies Omaliinae, Proteininae, Pselaphinae, Tachyporinae and Oxytelinae), Bulletin of the North-East Science Center. 2, 59-68 [In Russian].

Sazhnev, A. S., 2018. Materials to the Rove Beetles Fauna (Coleoptera: Staphylinidae) of the Commander Islands (Kamchatka Krai, Russia), Caucasian Entomological Bulletin. 14, 1, 19-23 [In Russian].

Schülke, M., Smetana, A., 2015. Family Staphylinidae Latreille, 1802, Catalogue of Palaearctic Coleoptera. 2/1. Hydrophiloidea - Staphylinoidea, Eds. I. Löbl, D. Löbl. Leiden ; Boston, Brill. 304-1134.

Smetana, A., 1971. Revision of the Tribe Quediini of America North of Mexico (Coleoptera, Staphylinidae), Memoirs of the Entomological Society of Canada. 79.

Yacobson, G. G., 1905-1915. Beetles of Russia and West Europe. St. Petersburg [In Russian]. 